\title{
Diseases Diversity for Flax Genetic Resources in Latvia
}

\author{
Inga Stafecka ${ }^{1}$, Dace Grauda ${ }^{2}$, Veneranda Stramkale ${ }^{1}$ \\ 1 - Institute of Agricultural Resources and Economics, Research Centre of Priekuli. \\ E-mail: inga.stafecka@arei.lv \\ 2 - University of Latvia, Institute of Biology University of Latvia
}

\begin{abstract}
Flax (Linum usitatissimum L) yield of stem and seeds and them quality is influenced by a number of harmful diseases but investigation about pathogens in recent years have not been done in Latvia. Each stage of development of disease is important in the pathogen life cycle and requires certain condition. Goal of this study have identify possibilities of the pathogens and were assess disease severity depending on the genotypes on flax in variable environmental conditions. The resistance to the diseases for 24 flax genotypes and standard variety 'Vega 2' were evaluated. The field trials have been carried out over the period from 2015 to 2016 at the Research Centre of Priekuli, part of Vilani in Latgale. Disease progress was measured every week, and for each treatment, severity of diseases index and the area under the disease progressive curve $(A U D P C)$ were calculated. The flow cytometry method for detection of flax pathogens was developed. The Fusarium avenaveum was dominating disease and statically significant in both vegetation periods. In 2015 were identified statically significant $(p<0.001)$ highest AUDPC the casual agents powdery mildew (Oidium lini) and of stem break and browning caused by Polyspora lini but in 2016 anthracnose (Colletotrichum lini), pasmo (Septoria linicola) and fusarium wilt caused by fungus Fusarium oxysporum $f$. sp. lini. The resistance of Colletotrichum lini, Fusarium oxysporum $f$. sp. lini, Septoria linicola and Oidium lini have flax variety of 'Rezekne' in both years.
\end{abstract}

Keywords: AUDPC, diseases, flax, flow cytometry, pathogens.

\section{INTRODUCTION}

Flax (Linum usitatissimum $\mathrm{L}$ ) is an important crop whose seed oil and stem fibre have multiple industrial applications.

Diseases of flax can be divided into two groups: the first group includes roots mycosis and diseases caused by soil resident fungi as Fusarium oxysporum f. sp. lini, Fusarium avenaceum, Septoria linicola as well Polyspora lini. The second group includes diseases of stems and leaves as Oidium lini and Colletotrichum lini. All detected fungus of flax is economically important diseases that can result in severe yield losses.

Fusarium wilt is the most frequently encountered disease in most countries in Europe, causing loss of $80-100 \%$ of yield [1], [2]. Another dangerous disease of fibre flax is anthracnose, which is caused by Colletotrichum lini [3]. It occurs all over the world in regions where flax is cultivated as Byelorussia, Czech Republic, Lithuania, Ukraine and France [4]. Occurrence of Oidium lini also known as powdery mildew was detected in $50-60 \%$ of cases in the last century in England and Germany especially connected with the decrease of yield in the range 5 $20 \%$ [4]. Recently, pasmo caused by Septoria linicola and powdery mildew have been widespread causing local disease epidemics in Western Canada [5]. In
Poland, pasmo was a quarantine disease until recently, and so does not occur there [6].

The most commonly practiced disease control method is the use of resistance varieties combined with effective crop rotations [7]. However, the resistance among varieties can differ due to the variability of pathogen races in different geographical regions with varying temperatures and environmental conditions [8]. High plant density on the field (1800 plants $\mathrm{m}^{-2}$ ) creates microorganisms and promotes infections and the development of diseases [4].

Progress of disease on plants is usually observed several times during pathogen epidemics. Extent of disease is assessed at each observation using scales that are based on disease incidence, severity, or a combination of both. To combine these repeated observations into a single value, Van der Plank (chapter 12 of literature citation 13) proposed calculating the area under the disease progress curve (AUDPC) [9] for summarizing and comparing plant disease epidemics.

The flow cytometry has been applied to address questions in infection biology [10] and it is still a relatively new technique for plant disease detection application [11]. In this research used for analysed questions related to intracellular infection for cell counting and sorting, biomarker detection. This might be solution that could help them identify pathogen http://dx.doi.org/10.17770/etr2017voll.2548 
infections in crops in a rapid, real-time and nondestructive fashion so that timely intervention and preventative treatments can be performed to contain the infection and minimize the crop losses.

Aim of this study was to determine diseases diversity for flax genetic resources by used calculating the area under the disease progress curve for each causal agent and developed flow cytometry methods for detection of flax pathogens.

\section{MATERIALS AND METHODS \\ A. Field experiments}

The field trials were conducted over the period from 2015 to 2016 at the Research Centre of Priekuli, part of Vilani in Latgale. Plants were grown in random block plots $1 \mathrm{~m}^{2}$ with a distance between rows $10 \mathrm{~cm}, 1700$ flax seeds per $1 \mathrm{~m}^{2}$ were sown by hand with sowing depth $1.5-2 \mathrm{~cm}$. Prior to that sowing seeds' germination tests were performed for all used genotypes. Seeds were sown between $1^{\text {st }}$ and $2^{\text {nd }}$ decades of May. Flax was grown in humipodzolic gley soil. The main agrochemical parameters of the arable soil layer were following: humus content $-6.5 \%, \mathrm{pH}_{\mathrm{KCl}}-6.4-7.0$, available $\mathrm{P}_{2} \mathrm{O}_{5}-130-145 \mathrm{mg} \mathrm{kg}^{-1}$ and available $\mathrm{K}_{2} \mathrm{O}-118-124$ $\mathrm{mg} \mathrm{kg}{ }^{-1}$ soil (by results of State Plant Protection Service). Complex fertilizer NPK 16:16:16 - $300 \mathrm{~kg}$ $\mathrm{ha}^{-1}$ was applied after first soil cultivation. For plants' further development a surface fertilizer - ammonium nitrate $30 \mathrm{~kg} \mathrm{~N} \mathrm{ha}^{-1}$ in "fir tree" phase was applied.

B. Evaluated diseases for flax varieties and lines

Experimental material for the present study consisted of 24 Latvian origins flax lines, varieties and all results was compared with standard variety 'Vega 2'.

The causal agent is the fungus were assessed for 30 plants of flax at the $1 \mathrm{~m}^{2}$ plots, every seven days till flax pulling and by estimating the disease severity index. Disease incidence was estimated by visual symptoms. The affected plant parts were stored in a wet chamber, and after emergence of mycelium the samples were examined with light microscope methods. The disease severity was recorded by following a five-point scale: 0 - healthy plant; 1 weakly affected; 2 - moderately affected; 3 - heavily affected; 4 - very heavily affected or dead plant. Disease severity index was calculated by applying formula (1):

$$
\mathrm{I}=\frac{\sum(\mathrm{ab}) \times 100}{\mathrm{~A} \cdot \mathrm{S}}
$$

Where I - disease severity index $\%$, a - number of infected plants, b - degree of infection, A - total number of plant samples (healthy and infected), S the highest degree if infection [12].

The combine these repeated observations into a single value have been calculated the area under the disease progress curve (AUDPC) by applying formula (2):

$$
A U D P C=\sum_{i=1}^{n-1} \frac{y_{i}+y_{i+1}}{2} \times\left(t_{i+1}-t_{i}\right)
$$

Where yi is an assessment of a disease (percentage) at the ith observation, ti is time (in days) at the ith observation, and $\mathrm{n}$ is the total number of observations [9], [13].

\section{Meteorological conditions}

Agro-meteorological conditions determined by ADCON installed meteorological stations which are connected to the computer program Dacom Plant Plus. Facility provides information in direct nearby field trials.

The amount of precipitation in 2016 growing period was by $45 \%$ higher and in 2015 by $6 \%$ lower in comparison to the long-term average of $311 \mathrm{~mm}$ (by 1. Fig.). According to the air temperature in 2015 average air temperature was $13.26^{\circ} \mathrm{C}$ and in 2016 , it was $14.00^{\circ} \mathrm{C}$, respectively, while the long-term average result is $13.00^{\circ} \mathrm{C}$.

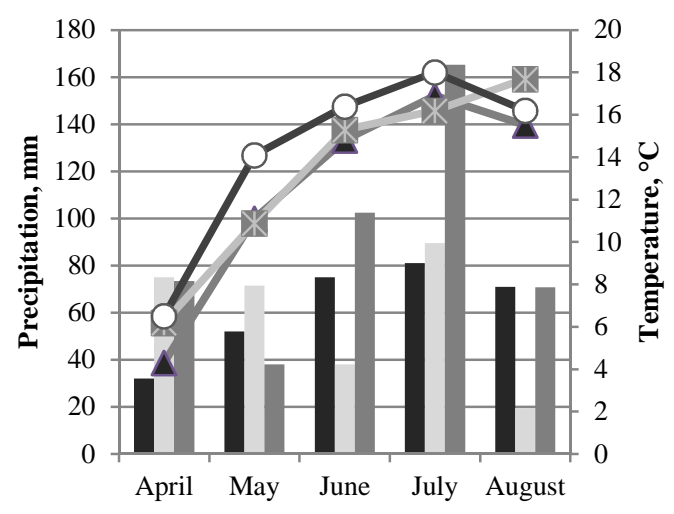

$$
\begin{aligned}
& \text { long-term average (precipitation) } \\
& 2015 \\
& 2016 \\
& -\quad \text { long-term average (temperature) } \\
& -3-2015 \\
& -\infty-2016
\end{aligned}
$$

Fig. 1. 2015-2016 sum of precipitation (mm) and average of air temperature $\left(\mathrm{C}^{\circ}\right)$ value in vegetation period of flax

\section{Data analysis}

MS-Excel software was used for data statistical analysis [14]. Used data analysis tools Descriptive Statistics, Anova: Single Factor and t-Test. Evaluated AUDPC for each flax disease were detected flax genotypes susceptibility level [9]. In Anova: Single Factor used Fisher's protected least significant difference (LSD) for the compare means AUDPC of genotypes.

\section{E. Flow cytometry methods}

Samples were prepared for flow cytometry with a DNA staining kit (SysmesPartec, PI Absolute, $\mathrm{GmbH}$, Germany) according to protocol with some modifications. For each sample, approximately $50 \mathrm{mg}$ 
of dry leaf material was excised and placed into a glass Petri dish $(60 \times 15 \mathrm{~mm})$. Dry material was chopped in $500 \mu \mathrm{L}$ of $+4 \mathrm{C} 0$ cold extraction buffer. For removal of cell fragments the suspension was filtered through $40 \mu \mathrm{m}$ filter (Falcon, USA) into a 5 $\mathrm{mL}$ polypropylene cytometry tube (Falcon, USA), and $1.5 \mathrm{~mL}$ of staining buffer was added. Cells nuclei were stained with $10 \mu \mathrm{l}$ propidium iodide, and incubated in the dark for $24 \mathrm{~h}$ at $+4 \mathrm{C} 0$ before analysis by flow cytometry. BD FACSJazz ${ }^{\circledR}$ cell sorter (BD Biosciences, USA) with flow cytometer function was used to detect DNA content (C -value) of flax and flax pathogens. The device was equipped with 100 $\mu \mathrm{m}$ nozzle and used phosphate-buffered saline (BD PharmingenTM PBS, BD Biosciences, USA) as a sheath fluid. Cell counting events were triggered by forward- scattered signal. The excitation of the cell fluorescence was made by $488 \mathrm{~nm}$ Coherent Sapphire Solid State (blue) laser. Before measurements, flow cytometer was calibrated using SpheroTM rainbow calibration particles $(3.0-3.4 \mu \mathrm{m}$, BD Biosciences, USA) in phosphate buffered saline (PBS). The calibration was considered as successful if the coefficient of variance (CV) of the calibration particles relative fluorescence did not exceed $3 \%$.

\section{RESULTS AND DISCUSSION}

In the two flax sowing periods were detected six harmful flax diseases: Fusarium wilt (Fusarium oxysporum f. sp. lini) and Fusarium avenaceum, powdery mildew (Oidium lini) pasmo (Septoria linicola), anthracnose (Colletotrichum lini) and Polyspora lini. By Table 1 find out for Fusarium avenaveum and Colletotrichum lini statistical significant difference between genotypes but not between years.

The Fusarium avenaceum was observed in two vegetation period. The fungus of causal agent Fusarium avenaveum was dominating disease in both vegetation periods from all detected diseases of flax. The sum of AUDCP for causal agent have highest and statically significant between others diseases (at Fig. 2.). The lowest AUDCP value has flax line of 'T31-40-94' (by Table 1), who have good potential for moderately resistant. [15] reported that Fusarium avenaceum is a cosmopolitan plant pathogen with a wide and diverse host range and is reported to be responsible for disease on $>80$ genera of plants. That partially explains the high spread of diseases. By [16] the genetic foundation that allows $F$. avenaceum to infect such a wide range of host plant species and cope with such a diverse set of environmental conditions is currently not well understood.

The anthracnose (Colletotrichum lini) was observed in all vegetation period. The fungus of causal agent Colletotrichum lini was dominating disease in 2016 but for some genotypes in 2015. According [17], observation results showed that very rainy the flax stands were heavily lodged, and up to $35 \%$ of plants were affected by anthracnose.

Table I

The AUDPC average of flax lines and varieties for Fusarium avenaveum and Colletotrichum lini

\begin{tabular}{|l|l|l|l|}
\hline No. & Variety/line & $\begin{array}{l}\text { Fusarium } \\
\text { avenaceum }\end{array}$ & $\begin{array}{l}\text { Colletotrichum } \\
\text { lini }\end{array}$ \\
\hline 1. & S13/5-7/5-93 & $168^{\mathrm{ab}}$ & $50^{\mathrm{ab}}$ \\
\hline 2. & S32/4-8-93 & $270^{\mathrm{abcd}}$ & $90^{\mathrm{ab}}$ \\
\hline 3. & S53/8-3-93 & $142^{\mathrm{ab}}$ & $5^{\mathrm{a}}$ \\
\hline 4. & S64-17-93 & $204^{\mathrm{abc}}$ & $2^{\mathrm{a}}$ \\
\hline 5. & T11-6/2-15-94 & $190^{\mathrm{ab}}$ & $146^{\mathrm{ab}}$ \\
\hline 6. & T11-13/3-1-94 & $238^{\mathrm{abc}}$ & $27^{\mathrm{a}}$ \\
\hline 7. & T25/5-33/12-8-94 & $175^{\mathrm{ab}}$ & $21^{\mathrm{a}}$ \\
\hline 8. & T29-36/10-5-94 & $272^{\mathrm{abc}}$ & $68^{\mathrm{ab}}$ \\
\hline 9. & T29-36/7-1-94 & $484^{\mathrm{bcd}}$ & $191^{\mathrm{ab}}$ \\
\hline 10. & T31-40-94 & $136^{\mathrm{a}}$ & $139^{\mathrm{ab}}$ \\
\hline 11. & T36-26/4-8-94 & $279^{\mathrm{abcd}}$ & $316^{\mathrm{b}}$ \\
\hline 12. & K47-17/11-1-95 & $286^{\mathrm{abcd}}$ & $158^{\mathrm{ab}}$ \\
\hline 13. & K47-17/11-6-95 & $219^{\mathrm{abc}}$ & $257^{\mathrm{ab}}$ \\
\hline 14. & L2-14/6-97 & $253^{\mathrm{abcd}}$ & $104^{\mathrm{ab}}$ \\
\hline 15. & L11-11/10-97 & $176^{\mathrm{ab}}$ & $231^{\mathrm{ab}}$ \\
\hline 16. & L11-11/11-97 & $198^{\mathrm{abc}}$ & $247^{\mathrm{ab}}$ \\
\hline 17. & L19-6/15-97 & $163^{\mathrm{ab}}$ & $155^{\mathrm{ab}}$ \\
\hline 18. & L23-26/3-97 & $232^{\mathrm{abc}}$ & $155^{\mathrm{ab}}$ \\
\hline 19. & L26-47/1-97 & $169^{\mathrm{ab}}$ & $205^{\mathrm{ab}}$ \\
\hline 20. & Altgauzen & $296^{\mathrm{abcd}}$ & $26^{\mathrm{a}}$ \\
\hline 21. & Rezeknes & $430^{\mathrm{bcd}}$ & $4^{\mathrm{a}}$ \\
\hline 22. & Rota 1 & $375^{\mathrm{bcd}}$ & $70^{\mathrm{ab}}$ \\
\hline 23. & Rota 2 & $269^{\mathrm{abc}}$ & $9^{\mathrm{a}}$ \\
\hline 24. & Ruda 1 & 236 & $14^{\mathrm{a}}$ \\
\hline 25. & ST Vega 2 & $137^{\mathrm{ab}}$ \\
\hline LSD & & & 259 \\
\hline & & $56^{\mathrm{abc}}$ & \\
\hline
\end{tabular}

abcd Means followed by the same letters in each column are not statistically significant.

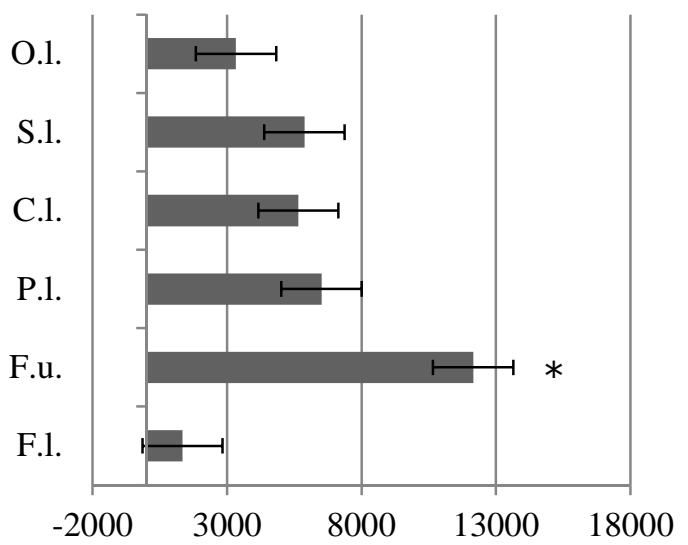

Fig.2. Summarized overview of AUDCP of 25 genotypes of flax by years. O.1. - Oidium lini, S.1. - Septoria linicola, C.1. Colletotrichum lini, P.1. - Polyspora lini, F.u. - Fusarium avenaveum, F.1. - Fusarium oxysporum f. sp. lini.* - statistically significant $\operatorname{LSD}_{0.05}(5995)$

In our case, due to the high moisture content in 2016 some genotypes by pathogens of the anthracnose had presented similar effect. By lowest AUDPC results was observed that resistant have flax line 'S64-17-93', 'S53/8-3-93' and variety 'Rezekne' in Table1.

As it is seen from Table 2 for casual agents caused by Fusarium oxysporum f. sp. lini, Septoria linicola, Oidium lini and Polyspora lini were showed 
statistical significant level $(\mathrm{p}<0.01)$ between years but don't between genotypes.

The fusarium wilt (Fusarium oxysporum f. sp. lini) was observed in the germination stage during two growing periods. The weather conditions were favourable for the spread of fusarium wilt causal agent in 2016. In 2016 disease AUDCP detected statistically significant highest for all genotypes except flax variety of 'Rezekne'. That genotype shows the resistant in both years. Between diseases the pathogens has the least amount value of AUDCP.
The fungus of causal agent Septoria linicola was detected visual symptoms on the plants only in 2016. The disease occurred in the flowering stage. In this during of vegetation period characterized with high and of heavy rainfall by partially lodged of flax. The similar results find out [18]. By [9] flax is most susceptible to pasmo in the ripening stage under moist conditions. According to [19] pasmo is spread by pycnidiaspores that are moved primarily by splashing rain. The fungus casual agents started spread to the greens leaves and later to the stems.

Table II

The AUDPC average of flax lines and varieties for Fusarium oxysporum f. sp. lini, Septoria linicola Oidium lini and Polyspora lini in both years

\begin{tabular}{|l|l|l|l|l|l|}
\hline No. & Variety/line & $\begin{array}{l}\text { Fusarium } \\
\text { oxysporum f. } \\
\text { sp. lini }\end{array}$ & $\begin{array}{l}\text { Septoria } \\
\text { linicola }\end{array}$ & $\begin{array}{l}\text { Oidium } \\
\text { lini }\end{array}$ & Polyspora lini \\
\hline 1. & S13/5-7/5-93 & 12 & 136 & 33 & 110 \\
\hline 2. & S32/4-8-93 & 23 & 195 & 60 & 169 \\
\hline 3. & S53/8-3-93 & 42 & 157 & 85 & 123 \\
\hline 4. & S64-17-93 & 16 & 104 & 96 & 179 \\
\hline 5. & T11-6/2-15-94 & 14 & 196 & 60 & 144 \\
\hline 6. & T11-13/3-1-94 & 18 & 117 & 77 & 126 \\
\hline 7. & T25/5-33/12-8-94 & 27 & 27 & 65 & 189 \\
\hline 8. & T29-36/10-5-94 & 12 & 77 & 96 & 150 \\
\hline 9. & T29-36/7-1-94 & 18 & 214 & 60 & 91 \\
\hline 10. & T31-40-94 & 34 & 149 & 69 & 205 \\
\hline 11. & T36-26/4-8-94 & 21 & 23 & 109 & 170 \\
\hline 12. & K47-17/11-1-95 & 23 & 43 & 97 & 185 \\
\hline 13. & K47-17/11-6-95 & 41 & 174 & 79 & 118 \\
\hline 14. & L2-14/6-97 & 36 & 112 & 72 & 124 \\
\hline 15. & L11-11/10-97 & 16 & 19 & 98 & 100 \\
\hline 16. & L11-11/11-97 & 50 & 41 & 73 & 87 \\
\hline 17. & L19-6/15-97 & 62 & 121 & 50 & 70 \\
\hline 18. & L23-26/3-97 & 42 & 95 & 33 & 58 \\
\hline 19. & L26-47/1-97 & 40 & 14 & 35 & 54 \\
\hline 20. & Altgauzen & 36 & 349 & 68 & 124 \\
\hline 21. & Rezeknes & 0 & 0 & 0 & 141 \\
\hline 22. & Rota 1 & 14 & 163 & 62 & 156 \\
\hline 23. & Rota 2 & 11 & 341 & 49 & 111 \\
\hline 24. & Ruda 1 & 12 & 34 & 61 & 137 \\
\hline 25. & ST Vega 2 & 53 & 40 & 80 & 136 \\
\hline Years* & & $\mathrm{p}<0.01$ & $\mathrm{p}<0.01$ & $\mathrm{p}<0.01$ & $\mathrm{p}<0.01$ \\
\hline & & & & \\
\hline & & & & \\
\hline & & & & \\
\hline
\end{tabular}

The [20] proved that the yield of susceptible varieties infected during flowering can be reduced by $75 \%$. In our case resistant observed of flax variety 'Rezekne' in both years.

The powdery mildew (Oidium lini) occurred in the green ripening stage. The weather conditions were favourable for the development of fungus in 2015. In this period contributed to the spread of fungus high rainfall in June and the low and hot weather in August. By [21], [22] powdery mildew the symptoms observed in different environments alludes to the presence of different races of the pathogen. In our case, causal agent has presented similar effect. The fungus pathogen rapidly started spread at the greens leaves and later at the stems and bolls. The resistant observed for flax variety 'Rezekne' in both years. But resistant of variety 'Rezekne' is due to the short vegetation period and genotype reason. By [23] classical genetic studies identified several resistant cultivars in the European cultivars Atalante and Linda.

The fungus of causal agent Polyspora lini was dominating disease in 2015 which characterise most dried and highest temperature like 2016. The weather conditions were favourable for the spread of fungal in all vegetation period in both years. The fungus is slower growing and disease noticeable later when the 
crop is on the advanced stage of growth [24]. The moderately susceptible has flax line of 'L26-47/1-97' and 'L23-26/3-97' against the disease.

Analysing the diverse infected parts of plants with flow cytometry method detected the presence of pathogens and their different cell size, number and position on the relative fluorescence graph. By Fig. 3 and Fig.4 find out that pathogen cells from flax infected plant material has haploid as well flax mixoploid. The specific pathogens of flax range on the graph (with $\mathrm{P}$ letter) by relative fluorescence units from $13^{1}$ until $10^{2}$ with different cell size in the Fig.3. and Fig.4.

The method for work in practice and to identify certain pathogens should to find out the specific fluorescence staining kits for identifies of the each disease characteristic position on the scale. Furthermore by [25], variations in genome size of plant pathogens can cause variation in pathogenicity and complicate the control of a disease. Our results are in agreement with [26] the correct expression of the genome size of fungi and fungus-like organisms is difficult, as they have complicated life cycles with different ploidy levels and the basic chromosome. Therefore important to take into account all of these to improve the method for flax pathogen detection.

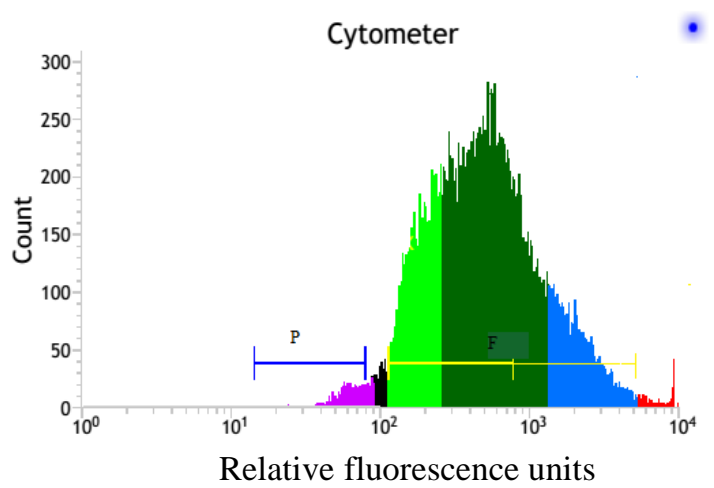

Fig 3. Graph derived from flow cytometry analysis showing relative fluorescence units (RFU) per cell. $\mathrm{P}$ range - pathogen and $\mathrm{F}$ range - flax line 'T11-6/2-15-94' plant material.

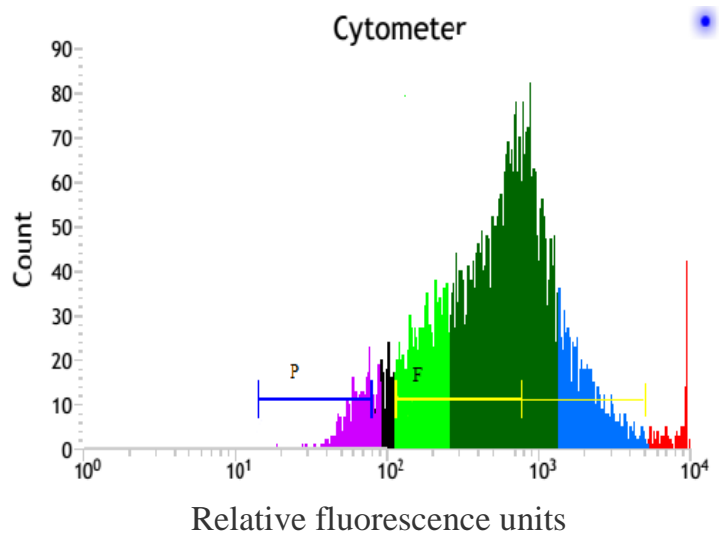

Fig 4. Graph derived from flow cytometry analysis showing relative fluorescence units (RFU) per cell. $P$ range pathogen and $F$ range flax line 'L2-14/6-97' plant material.

\section{CONCLUSIONS}

Environmental conditions in both 2015 and 2016 were favourable for Fusarium avenaceum development by highest statistically significant AUDCP level between all the others diseases.

There are substantial differences in disease development and severity between years and fields due to differences in pathogen population structure, resulting variable results. By AUDCP results showed resistant from the Colletotrichum lini, Fusarium oxysporum f. sp. lini, Septoria linicola, Oidium lini the flax variety of 'Rezekne' by years.

Flow cytometry methods could decrease the time and effort necessary for the development of resistant genotypes in breeding programs. However, this conclusion needs to be critically tested by evaluating more comprehensive samples and varieties as well find out specific fluorescence staining kits for pathogens.

\section{REFERENCES}

[1] X. Beaudoin, Disease and pest control. In: G. Marshall (Ed.): Flax: Breeding and Utilisation. Advances in Agricultural Biotechnology 25, Kluwer Academic Publishers, the Netherlands, pp. 81-88. 1989.

[2] L. C. Sharma and R. L. Mathur, Variability in first single spore isolates of Fusarium oxysporum f.sp. lini in Rajastan. Indian Phytopathology 24:688-704, 1971.

[3] K. Y. Rashid, Principal diseases of flax. In: Muir, A.D., Westcott, N.D. (Eds.), Flax: The Genus Linum. Taylor and Francis Ltd, New York, NY, 2003 pp. 92-123.

[4] R. M. Kozlowski, Hanbook of natural fibres. Woodhead Publishing Series in Textiles: Number 118, Volume 1, 2012, pp $390-523$.

[5] H. Booker, R. Bueckert, S. Duguid, J. Gavloski, R. Gulden, R. Dueck, ... A. Ulrich, „Growing Flax Guide”, 2014 Retrieved January 20, 2017from http://flaxcouncil.ca/growingflax/growth-and development/

[6] K. Heller, Crop management of fibre flax in Europe, Presentation Summer school, Catania - Italy, 2013. Retrieved January 18, 2017 http://www.fibrafp7.net/Portals/0/06_Heller.pdf.

[7] L.M. Hall, H. Booker, R. M. P. Siloto, A. J. Jhala, R. J. Weselake, Flax (Linum usitatissimum L.) Industrial Oil Crops, First Edition, 2016, pp 157-194.

[8] K. Y. Rashid and E. O. Kenaschuk, Effect of trifluralin on fusarium wilt in flax. Can. J. Plant Sci. 1993, 73: 893-901.

[9] I. Simko and H. P. Piepho, The Area Under the Disease Progress Stairs: Calculation, Advantage, and Application Phytopathology Vol. 102, No.4, 2012 pp 381-389.

[10] V. Haridasa, S. Ranjbara, I. A. Vorobjevc, A. E. Goldfelda, N. S. Bartenevaa, Imaging flow cytometry analysis of intracellular pathogens. Methods. Volume 112, 1 January 2017, Pages 91-104 Flow Cytometry.

[11] L.G. Chitarra; van den Bulk, R.W. The application of flow cytometry and fluorescent probe technology for detection and assessment of viability of plant pathogenic bacteria. Eur. J. Plant Pathol. 2003, 109, 407-417.

[12] Н. И. Лошакова, Т. В. Крылова, Л. П. Кудрявцева, „Методические указания по фитопатологической оценке устойчивости льна-долгунца к болезням” - Москва,- 52 с. 2000.

[13] J. E. Van der Plank, „Plant Diseases: Epidemics and Control.” Academic Press, New York. 1963.

[14] I. Arhipova, un S. Bāliṇa, ,Statistika ekonomikā. Risinājumi ar SPSS un Microsoft Excel." (Statistics in the economy. The solutions with SPSS and Microsoft Excel.) 2. iss. Rìga: Datorzinību Centrs, 2006, pp. 364. (in Latvian). 
[15] M. C. Leach, S. L. A. Hobbs, „Plantwise knowledge bank: delivering plant health information to developing country users." Learned Publ 26: 180-185, 2013.

[16] E. Lysøe, L. J. Harris S. Walkowiak R. Subramaniam H. H. Divon E. S. Riiser C. Llorens T. Gabaldón H. C. Kistler W. Jonkers A. K. Kolseth K. F. Nielsen U. Thrane R. J. Frandsen „The genome of the generalist plant pathogen Fusarium avenaceum is enriched with genes involved in redox, signaling and secondary metabolism." PLoS One. 2014 Nov 19;9(11).

[17] K. Bačelis, E. Gruzdevienè, Resistance of fibre flax varieties to Colletotrichum lini Manns et Bolley // Biologija. - 2001. Nr. 3, p. 4-7. (ISSN: 1392-0146) (http://www.elibrary.lt/ resursai/LMA/Biologija/B-033.pdf).

[18] E. Gruzdeviene, The Peculiarities Of The Occurrence Of Pasmo Disease (Septoria linicola) In Central Lithuania Zemdirbyste-Agriculture, vol. 95, No. 3 (2008), p. 58-64.

[19] K. Y. Rashid, K. L. Bailey, B. D. Gossen, R. K. Gugel, and R. A. A. Morrall, Diseases of flax. Diseases of Field Crops in Canada, 3rd ed. eds. University Extension Press, Saskatoon, SK, Canada, 2003. Pages 147-154

[20] W. E. Saskston, „Pasmo - past, present, and future.” In: Proceedings of the Flax Institute of the United States, November 19th, 1959, Fargo, North Dakota, U.S.A., 1959 pp. 3-5.
[21] R. E. Beale, „Studies of resistance in linseed cultivars to Oidium lini and Botrytis cinerea." Aspects Appl. Biol. 1991, 28:85-90.

[22] G. S. Saharan and M. S. Saharan, Studies on powdery mildew of linseed caused by Leveillula taurica (Lev.). Indian J. Mycol. Plant Pathol. 1994, 24:107-110.

[23] K. Rashid and S. Duguid., Inheritance of resistance to powdery mildew in flax. Can. J. Plant Pathol. 2005, 27: 404-409.

[24] E. Gruzdeviene, General problems and control of fungal diseases of flax in Lithuania // Development of Environmentally Friendly Plant Protection in the Baltic Region: proceedings of the International Scientific Conference. - Tartu, 2000, p. 40-42.

[25] R. T. Gregory, J. A. Nicol, H. Tamm, B. Kullman, K. Kullman, I. J. Leitch, B. G. Murray, D. F. Kapraun, J. Greilhuber and M. Bennet, „Eukaryotic genome size databases". Nucleic Acids Res. 35, (2007) 332- 338.

[26] L. D'Hondt, M. Höfte V. E. Bockstaele and L. Leus Applications of flow cytometry in plant pathology for genome size determination, detection and physiological status. Molecular Plant Pathology. 2011 pp 1-14. 